Jurnal Penelitian dan Pengabdian Kepada Masyarakat Bidang ilmu Pendidikan

\title{
Upaya Meningkatkan Kemampuan Guru dalam Melaksanakan Penilaian Berbasis Kelas melalui Bimbingan Klinis di SMA Negeri 1 Woja
}

\author{
Eva Patriani \\ SMA Negeri 1 Woja, Kabupaten Dompu, Nusa Tenggara Barat \\ E-mail: evapatriani.sma1dompu@gmail.com
}

Article History: Received: 2020-10-09 || Revised: 2020-11-03 || Published: 2020-12-26

Sejarah Artikel : Diterima: 2020-10-09 || Direvisi: 2020-11-03 || Dipublikasi: 2020-12-26

\begin{abstract}
This study aims to improve the ability of teachers to carry out class-based assessments through clinical supervision at SMA Negeri 1 Woja in Dompu Regency. This research is classified as an action research by Seklah involving 12 existing teachers. The research was conducted in two cycles and each cycle consisted of four stages, namely: planning, implementing, observing and reflecting. The determined performance indicators are: The teacher is successful in carrying out the classroom assessment if the teacher has met the criteria of getting a score of more or equal to 77.8 (with a good category). From the analysis, it was found that there was an increase in the quality of the implementation of teacher assessments from the first cycle of 67 with a sufficient category to the second cycle of 79 with a good category. Thus it can be concluded that through the optimization of clinical supervision can improve classroom-based assessments, teachers of SMA Negeri 1 Woja in Dompu Regency. Therefore, it can be suggested to supervisors or other researchers that the optimization of clinical supervision activities can be used as an alternative in improving the quality of teacher assessment.
\end{abstract}

Keywords: Supervisi klinis, peningkatan penilaian berbasis kelas.

\begin{abstract}
Abstrak
Penelitian ini bertujuan untuk meningkatkan kemampuan guru dalam melaksanakan penilaian berbasis kelas melalui supervisi klinis pada SMA Negeri 1 Woja Di Kabupaten Dompu . Penelitian ini tergolong penelitian tindakan Seklah dengan melibatkan 12 orang guru yang ada. Penelitian dilakukan dengan dua siklus dan masing-masing siklus terdiri atas empat tahapan, yakni: perencanaan, pelaksanaan, observasi dan refleksi. Indikator kinerja yang ditetapkan adalah: Guru berhasil dalam melaksanakan penilaian kelas bila guru sudah memenuhi kereteria memperoleh sekor lebih atau sama dengan 77,8 (dengan kategori baik). Dari analisis diperoleh bahwa terjadi peningkatan kualitas pelaksanaan penilaian guru dari siklus I sebesar 67 dengan kategori cukup ke siklus II sebesar 79 dengan kategori baik. Dengan demikian dapat disimpulkan bahwa melalui optimalisasi supervise klinis dapat meningkatkan penilaian berbasis kelas, guru SMA Negeri 1 Woja Di Kabupaten Dompu. Oleh karena itu dapat disarankan kepada pengawas atau peneliti yang lain bahwa optimalisasi kegiatan supervise klinis dapat dipakai sebagai salah satu alternatif dalam meningkatkan kualitas pelaksanaan penilaian guru.
\end{abstract}

Kata kunci: Clinical supervision, class-based assessment improvement.

\section{PENDAHULUAN}

Penilaian merupakan rangkaian kegiatan untuk memperoleh, menganalisis, dan menafsirkan data tentang proses dan hasil belajar peserta didik yang dilakukan secara sistematis dan berkesinambungan, sehingga menjadi informasi yang bermakna dalam pengambilan keputusan. penilaian berbasis kelas, yaitu bagian dari kegiatan pembelajaran yang dilakukan untuk mengetahui pencapaian kompetensi peserta didik yang meliputi pengetahuan, keterampilan, dan sikap. Penilaian dilakukan selama proses pembelajaran dan/atau pada akhir pembelajaran. Fokus penilaian pendidikan adalah keberhasilan belajar peserta didik dalam mencapai standar kompetensi yang ditentukan. Pada tingkat mata pelajaran, kompetensi yang harus dicapai berupa Standar Kompetensi (SK) mata pelajaran yang selanjutnya dijabarkan dalam Kompetensi Dasar 
(KD).

Kualitas pendidikan sangat ditentukan oleh kemampuan guru dalam mengelola proses pembelajaran. Penilaian merupakan bagian yang penting dalam pembelajaran. Dengan melakukan penilaian, guru sebagai pengelola kegiatan pembelajaran dapat mengetahui kemampuan yang dimiliki siswa, ketepatan metode mengajar yang digunakan, dan keberhasilan siswa dalam meraih kompetensi yang telah ditetapkan. Berdasarkan hasil penilaian, guru dapat mengambil keputusan secara tepat untuk menentukan langkah yang harus dilakukan selanjutnya. Hasil penilaian juga dapat memberikan motivasi kepada siswa untuk berprestasi lebih baik. Sebagaimana diketahui bahwa SMA Negeri 1 Woja Di Kabupaten Dompu mempunyai jumlah dan variasi siswa yang beragam baik dilihat dari segi sosial, ekonomi dan budaya, sedangkan dari variasi siswa tidak dapat dipungkiri bahwa banyak diantaranya mempunyai kemampuan baik secara fisik, emosional, intelektual yang beragam pula. Undang-undang Pendidikan Nasional No 20 tahun 2003, pasal 1 ayat 1 . menyatakan bahwa

"Pendidikan merupakan usaha sadar dan terencana untuk mewujudkan suasana belajar dan proses pembelajaran agar peserta didik secara aktif mengembangkan potensi diri nya untuk memiliki kekuatan spiritual keagamaan, pengendalian diri, kepribadian kecerdasan, akhlak mulia, serta keterampilan yang diperlukan dirinya, masyarakat, bangsa dan negara".

Pernyataan Undang-Undang diatas tentu memberikan konsekwensi logis bagi terlaksananya sistem pendidikan yang adil, merata, dan memberikan kesempatan belajar bagi semua siswa tanpa kecuali. Sejalan dengan pernyataan diatas, penilaian berbasis kelas harus dilaksanakan secara terencana dan bekesinambungan. Namun dilapangan masih banyak ditemukan kejanggalankejanggalan dalam pelaksanaan penilaian yang dilakukan oleh guru. Berdasarkan hasil studi awal dari supervisi kelas yang dilakukan sebelum penelitian ini ditemukan, masih ada guru yang melaksanakan kegiatan belajar-mengajar tanpa persiapan. Persiapan yang hendaknya wajib dilakukan oleh guru adalah membuat program tahunan, program semester, rencana pembelajaran, rancangan penilaian/buku nilai, agenda mengajar, daftar hadir siswa, serta buku catatan khusus terhadap anak yang bermasalah.

Begitu pula pada akhir proses belajar-mengajar belum sepenuhnya diadakan evaluasi sehingga pokok bahasan yang dipelajari belum terukur apakah siswa sudah memahami atau telah menyerap pelajaran tersebut. Para guru juga masih berorientasi pada bahan, bukan pada tujuan pembelajaran sehingga yang menjadi target para guru yakni habis materi seolah-olah tujuan telah tercapai. Selain itu masih ditemukan guru belum membuat persiapan penilaian kelas yang lengkap dari pembuatan kereteria ketutuntasan minimal, kisi-kisi soal, analisis soal, dan setelah penilaian hasilnya tidak segera dibagikan kepada siswa, analisis serta hasil ketuntasan belajar siswa, ini penting dilakukan guru dalam penilaian berbasis kelas.

Sehubungan dengan hal tersebut tampaknya perlu diadakan pembinaan-pembinaan melalui supervisi klinis. Supervisi klinis ini lebih berorientasi pada kegiatan guru di dalam kelas. Penekanan supervisi klinis adalah pengobatan atau penyembuhan yang diwujudkan dalam bentuk tatap muka antara supervisor (pembimbing) dengan guru. seperti yang diungkapkan oleh Ngalim Purwanto (1987) bahwa supervisi ialah suatu aktivitas pembinaan yang diharapkan dapat meningkatkan kemampuan sekolah maupun guru. Pemberian layanan/pembinaan kepada guru-guru ini dapat dilakukan secara individual maupun secara berkelompok, dalam usaha memperbaiki pengajaran dengan tujuan untuk mengembangkan situasi belajar mengajar.

\section{METODE PENELITIAN}

Penelitian ini tergolong penelitian tindakan sekolah dengan melibatkan 12 orang guru yang belum mampu melaksanakan penilaian kelas secara maksimal. Penelitian dilakukan dengan 2 (dua) 
siklus dan masing-masing siklus terdiri atas empat tahapan, yakni: perencanaan, pelak-sanaan, observasi dan refleksi. Parameter refleksi yang ditetapkan adalah: Guru berhasil dalam melaksanakan penilaian kelas bila guru sudah memenuhi kereteria yakni memperoleh sekor lebih atau sama dengan 77,8 (kategori baik). Jika kurang dari 77,8 dikatakan gagal sehingga wajib mengikuti siklus berikutnya.

\section{HASIL DAN PEMBAHASAN}

Berdasarkan hasil analisis pada masing-masing siklus ditemukan bahwa terjadi peningkatan aktivitas guru dalam kegiatan penilaian kelas pada SMA Negeri 1 Woja Di Kabupaten Dompu dan terjadi peningkatan kemampuan guru dalam melengkapi perangkat penilaian melalui pembinaan supervisi klinis guru SMA Negeri 1 Woja Di Kabupaten Dompu dari siklus I sebesar 67 dengan kategori Cukup, ke siklus II sebesar 79 dengan kategori Baik. Dengan demikian dapat disimpulkan bahwa hasil penelitian yakni, melalui pembinaan supervise klinis dapat meningkatkan kemampuan guru dalam melaksanakan penilaian kelas pada SMA Negeri 1 Woja Di Kabupaten Dompu . Hasil penelitian ini berkaitan dengan apa yang dikatakan Achesan dan Gall dalam (Mantja. 2005) Mereka mengemukakan bahwa supervisi klinis merupakan proses membantu guru untuk memperkecil ketidaksesuaian (kesenjangan) antara perilaku mengajar yang aktual dengan perilaku mengajar yang ideal.

\section{SIMPULAN DAN SARAN}

\section{A. Simpulan}

Berdasarkan analisis dan pembahasan seperti yang telah dipaparkan pada bagian sebelumnya ditemukan bahwa terjadi peningkatan kemampuan guru dalam melengkapi perangkat dan aktivitas penilaian melalui pembinaan supervisi klinis guru pada SMA Negeri 1 Woja Di Kabupaten Dompu , dari siklus I sebesar 67 dengan kategori Cukup, ke siklus II sebesar 79 dengan kategori Baik. Sehingga dapat disimpulkan bahwa melalui pembinaan supervise klinis dapat meningkatkan kemampuan guru dalam melaksanakan penilaian kelas pada SMA Negeri 1 Woja Di Kabupaten Dompu.

\section{B. Saran}

Beberapa saran yang dapat peneliti sajikan yaitu: 1) Agar pembinaan prosedur dan teknis penilaian dapat berjalan secara efektif, maka semua peserta (guru) harus mampu bekerjasama dengan peserta lain yang bersifat kolaboratif konsultatif, 2) Kemampuan melaksanakan Penilaian akan berjalan dengan efektif bila semua komponen sekolah tahu betul prosedur penilaian berbasis kelas 3) Pembinaan dalam bentuk supervise klinis, dapat dijadikan salah satu alternatif dalam mening-katkan kemampuan sekolah dalam melaksanakan penilaian berbasis kelas.

\section{DAFTAR RUJUKAN}

Arikunto Suharsimi. 2002. Prosedur Penelitian Suatu Pendekatan Praktek. Jakarta: Bumi Aksara.

Arikunto Suharsimi. 2008. Penelitian Tindakan Kelas. Jakarta: PT. Bumi Aksara.

Departemen Pendidikan Nasional. 2003. Undang Undang Republik Indonesia Nomor 20 Tahun 2003 Tentang Sistem Pendidikan Nasional. Jakarta : PT Kloang Klede Putra Timur

Fathirma'ruf, F., \& M. Said, B. (2020). Pengembangan Perangkat Pembelajaran Konstruktivistik Model Teaching with Analogies (TWA) pada Mata Kuliah Database Management System (DBMS) untuk Meningkatkan Kemampuan Berpikir Kreatif Mahasiwa.Jurnal Teknologi Informasi dan Ilmu Komputer, 7(5), 1051-1060. doi:http://dx.doi.org/10.25126/jtiik.2020752388

Lie, A. 2002. Cooperative Learning, Gramedia Wdyasarana Indonesia ,Jakarta 
Mantja, W. 2005. "Supervisi Klinik: Peranan Supervisi Kepala sekolah Dalam Rangka Meningkatkan Profesionalisme Guru SMP, SMA, SMK Se Kabupaten Buleleng". Makalah disampaikan pada seminar sehari pada tanggal 28 JUni 2005 di Singaraja.

Nur, M dan Wikandari. 2000. Pengajaran Berpusat pada Siswa dan Pendekatan Konstruktivis dalam Pengajaran. Surabaya: PSMS.

Panitia Penerimaan Siswa Baru. 2008. Data Penerimaan Siswa Baru SMA Negeri 1 Kempo. (Tidak Dipublikasikan).

Samani, M. 2006. Menjadi Guru Profesional dalam Persepektif UU Guru dan Dosen. Makalah. Disampaikan pada workshop Guru Berprestasi Nasional. Bandung, 29 Mei 2006.

Sudjana, Nana. 2004. Penilaian Hasil Proses Belajar Mengajar. Bandung.Remaja Rosdakarya.

Suharsimi Arikunto,2008. Dasar-dasar Evaluasi Pendidikan (Edisi Revisi), cetakan kedelapan, Penerbit Bumi Aksara.

Suyitno, Amin. 2006. Pemilihan Model-Model Pembelajaran dan Penerapannya di Sekolah. Semarang : Universitas Negeri Semarang 